\title{
Factors Affecting Stadium Attendance of Professional Football Club Supporters
}

\author{
Aydogan Soyguden ${ }^{1}$, Robert C. Schneider ${ }^{2}$, Yasar Barut ${ }^{3}$, Osman Imamoglu ${ }^{3}$ \\ Erciyes University ${ }^{l}$, Kayseri, Turkey \\ State University of New York the College at Brockport ${ }^{2}$, Brockport, NY, USA \\ Ondokuz Mayis University ${ }^{3}$, Samsun, Turkey
}

\begin{abstract}
Background. The aim of this study was to investigate factors affecting the stadium attendance of the supporters of professional football clubs that have stadiums meeting the UEFA criteria.

Methods. The study population included the supporters of Galatasaray Sport Club, Fenerbahce Sport Club and Kayserispor football clubs participating in the Spor Toto Super League-Turkey in the 2013-2014 seasons and having stadiums that meet the UEFA criteria. The sample consists of randomly selected $(n=1237)$ supporters. Additionally, demographic data of the supporters, reasons affecting the Stadium Attendance and Non-Attendance Reason Scale (SANARS) which consists of 30 questions were used to collect the data. Statistical analysis of the data was done using the SPSS 16.0 packet program and descriptive statistics, independent $t$-test and one-way ANOVA test were performed.

Results. Generally, factors affecting the stadium attendance of the supporters were as follows: opportunity for recreational activities, stadium atmosphere, and personal relaxation. On the other hand, the factors generally affecting the supporters' nonattendance were as follows: negative ergonomic environment and unethical situations.

Conclusion. Among the factors affecting the supporters' attendance in the stadiums, the component of "Opportunity for Recreational Activities" was found to be the most influential factor. This revealed the necessity of increasing the number of high quality organizations related to recreational activities in the stadiums. In this study, the factor of "Negative Ergonomic Environment" was found to be the most influential factor influencing stadium attendance. In conclusion, negative ergonomic environmental conditions need to be improved to increase stadium attendance.
\end{abstract}

Keywords: fans (supporters), Football, Stadium Attendance and Non-Attendance, UEFA stadium criteria.

\section{INTRODUCTION}

$\mathrm{P}$ rofessional football teams and fans complement each other. These two elements are formed in accordance with the demands of the other. Each is dependent on the other. Weakness in professional football teams and/or fan attendance can affect the other. The aim of this study was to examine the factors that affect professional football fan stadium attendance.

As sports clubs increase their revenue efforts, sports organizations should, in turn, begin to increase in popularity because of the subsequent increases in both media coverage of the sport organization, and marketing-oriented sport industry restructuring (Ekmekçi, 2009). Today football has become an industrial sector and not only generates ticket sales and match day revenue, but is also earning from many different areas such as media broadcasting, sponsorship, merchandise, and advertising revenues (Aksar, 2005).

Generally, sports clubs must consider the main revenue and expenditure items of particular football clubs when operating the club. As income, which include advertising and sponsorship revenues, and income derived from the sale of broadcasting 
rights? Additionally, ticket sales are comprised of operating income and product revenues related to the stadium are considered income. On the expenditure side, costs related to athletes such as salaries, recruiting and transfer/trading costs in addition to operational and administrative business costs are primary expenditure obligations (Kotab \& Scholleva, 2011).

In a study conducted between major football teams from the years 1994-2000 in Europe, soccer teams who become champions in the national football league or international football organization claimed that they increased revenues related to advertising, sponsorship, participation fee, uniform sales, and incomes related to stadiums and broadcasting (Solberg \& Gratton, 2004). Some studies in the atmosphere of sports stadiums found that due to the positive impact of the sport on an audience, that audience became interested in attending additional sporting events (Madrigal, 1995; Wakefield \& Blodgett, 1999, 1994).

The following multiple factors were considered to be important determinants of stadium fan attendance: market size, ticket prices, homeowners and visitors' performance, the day of the week the game was played, in which league the game was played (such as the UEFA League), and the distance between the teams playing was reported to affect fan attendance (Deschriver, Rascher \& Shapiro, 2013). In some works, new sports facilities were found to be effective in increasing fan attendance, which was found to usually last less than 10 years (Austrian \& Rosentraub, 1997; Clapp \& Hakes, 2005; McEvoy, Nagel, DeSchriver, \& Brown, 2005).

A variety of physical and social research for effective stadium environments has been carried out. Stadium atmospheres that were found to stimulate high levels of fan attendance interests were generally driven by the enjoyment experienced by the fan while in the stadium (Uhrich \& Benkenstein, 2010). The importance of the live sporting events has been widely recognized as an important aspect in shaping the stadium's physical and social environment (Tombs \& McColl-Kennedy, 2003; Wakefield \& Blodgett, 1999; Westerbeek \& Shilbury, 1999; Wakefield \& Sloan, 1995).

Although the quality and atmosphere of the stadium are important (Argeris, Hunton, Williams, \& Nagel, 2013), a factor which is effective for drawing fans from the city center to the stadium is the stadium's placement near the city center.
According to sports marketing literature, the special atmosphere of the people who formed the sports stadium is one of the most important factors influencing fan attendance to that stadium (Bauer, Sauer, \& Exler, 2005; Holt, 1995; Pfaff, 2002).

Based on the sport marketing research, fan satisfaction, generally consists of two types: game satisfaction and service satisfaction (Yoshida \& James, 2010). In a study by Kelley and Turkey (2001), where service quality was surveyed, the most important factors expressed were stadium cleanliness, parking lot security, seat location, parking lot distance, and cleanliness of toilets. Team performance has been the most important factor affecting team attendance (Borland \& McDonald, 2003; Szymanski, 2003).

\section{METHODS}

In this section the following materials and methods are discussed: the population, research group, measuring tool, development of the scale, validity and reliability of the scale, pilot scale, and the data collection and analysis.

Research methods and primary population. The study population included the fans of the Galatasaray Sport Club, Fenerbahce Sport Club, and Kayserispor football clubs participating in Spor Toto Super League-Turkey in the 2013-2014 seasons, which all played in stadiums that meet the UEFA criteria.

Different studies examined standard deviation and in their power analysis performed they determined the number of subjects with $95 \%$ for confidence intervals and at least $80 \%$ test power in each group, and this was found to be sufficient for at least 384 to be the subjects.

A total of 1237 fans were surveyed from three different Super League teams. Subjects who participated in the survey were 1137 men (91.9\%) and 100 women $(8.1 \%)$, making for a total of 1237 fans.

Measuring Tool. In this study, factors affecting variables causing professional football fan attendance and non-attendance of matches were measured with the Social and Economic Situation scale form.

Development of Scale. To help identify professional football fan factors related to attendance, the Stadium Attendance and NonAttendance Reason Scale (SANARS) was developed. The SANAR scale was reviewed for 
content validity and modified by four faculty members working in the principal investigator's university, resulting in a 42 item scale used for this study. Feedback related to clarity of the scale was received after piloting the modified version to 50 students from the principal investigator's university and to 76 members of the 2013-2014 seasons in Turkey PTT 1.League, Samsunspor fans. Using results from the pilot study, the validity and reliability for the scale, through the application of SPSS, Cronbach's alpha value was determined to be above .70 .

Reliability and Validity of the Scale. The internal consistency results of the reliability analysis of 30 responses related to the cause of Stadium Attendance and Non-Attendance Reason Scale (SANARS) is presented here. Internal consistencies for the following questions that addressed reasons for fan attendance in stadiums were as follows: size of the stadium, .86; opportunities for recreation activities in the stadium, .85; stadium atmosphere, .70; opportunity for personal relaxation, .77 . general conditions of the stadium, .92; negative ergonomic environmental conditions .89; and unethical situations, .78. Reliability analysis of the rate of internal consistency was found to be above the acceptable lower limit of the ratio of .70; thus the scale was considered acceptable for adoption as reliable.

Data Collection. Scale form has been developed by the researchers. Literature studies of this Stadium Attendance and Non-Attendance Reason Scale (SANARS) was developed as a result of the pilot study and consisted of three parts. The first part was given to the 12-Item variables determining the fans demographic, social and economic status. The second part consists of 15 factors related to reasons affecting fan attendance to the stadium, and the third part consists of 15 factors related to reasons affecting fan non-attendance to the stadium. A five point Likert scale (5 = "Strongly agree", 4 = "agree", 3 = "undecided", 2 = "disagree", $1=$ "strongly disagreed") was provided for subjects to evaluate each factor related to each statement in sections two and three.

Data Analysis. The data were analyzed using descriptive statistical methods (frequencies, percentages, means, Standard deviation, and variances) were used. A $t$-test and ANOVA were used to test the hypotheses.

The statistical significance of $p<.05$ was adopted. Then the frequency and percentage distribution among the variables were calculated, their respective cross tables were created. Descriptive statistics, a factor analysis, an independent $t$-test and a one-way ANOVA test were applied.

\section{RESULTS}

The data obtained in this part of the study were demographic and socio-economic characteristics of the participants, the relationships between instadium factors related to fan attendance and non-attendance. Education and income were two variables also considered.

Table 1. Distribution according to age groups of participants

\begin{tabular}{|c|c|c|}
\hline Age & $N$ & $\%$ \\
\hline Under 15 & 25 & 2 \\
\hline $\mathbf{1 5 - 2 0}$ & $\mathbf{4 0 2}$ & $\mathbf{3 2 . 4}$ \\
\hline $\mathbf{2 1 - 2 5}$ & $\mathbf{4 0 2}$ & $\mathbf{3 2 . 4}$ \\
\hline $\mathbf{2 6}-\mathbf{3 0}$ & $\mathbf{1 8 1}$ & $\mathbf{1 4 . 6}$ \\
\hline $\mathbf{3 1 - 3 5}$ & 99 & 8 \\
\hline $\mathbf{3 6}-\mathbf{4 0}$ & 62 & 5 \\
\hline $\mathbf{4 1 - 4 5}$ & 34 & 2.7 \\
\hline Over 45 & 32 & 2.5 \\
\hline Total & 1237 & 100 \\
\hline
\end{tabular}

In Table 1, the majority of the match attendance fans (79.4\%) ranged between 15 to 30 years in age.

Table 2. Distribution according to football club fans groups of participants

\begin{tabular}{|l|c|c|}
\hline \multicolumn{1}{|c|}{ Club } & $\boldsymbol{N}$ & $\mathbf{\%}$ \\
\hline Galatasaray FC & 390 & 31.5 \\
\hline Fenerbahçe FC & 442 & 35.7 \\
\hline Kayserispor FC & 405 & 32.7 \\
\hline Total & $\mathbf{1 2 3 7}$ & $\mathbf{1 0 0}$ \\
\hline
\end{tabular}

Table 2 of displays the participants in the study, Galatasaray 390 fans (31.5\%), Fenerbahce 442 fans (35.7) and Kayserispor 405 fans (32.7), totaling 1237 fans (100\%) who participated in the survey.

Table 3 shows that the $56.7 \%$ of participants were university students and university graduates, $47.7 \%$ of participants were students.

Table 4 shows that $32.3 \%$ of participants were fans without any income. 
Table 3. Distribution according to education status of participants

\begin{tabular}{|l|c|c|c|c|c|c|c|c|}
\hline \multicolumn{1}{|c|}{ Educational Status } \\
\hline \multicolumn{1}{|c|}{ Club } & $\begin{array}{c}\text { Primary sch. } \\
\text { grad. }\end{array}$ & $\begin{array}{c}\text { Middle } \\
\text { Sch. Grad. }\end{array}$ & $\begin{array}{c}\text { High Sch. } \\
\text { Student }\end{array}$ & $\begin{array}{c}\text { High School } \\
\text { Grad. }\end{array}$ & $\begin{array}{c}\text { University } \\
\text { Student }\end{array}$ & $\begin{array}{c}\text { University } \\
\text { Grad. }\end{array}$ & Graduate & Total \\
\hline Galatasaray & 6 & 24 & 58 & 48 & 159 & 80 & 15 & 390 \\
(n, \%) & 1.5 & 6.2 & 14.9 & 12.3 & 40.8 & 20.5 & 3.8 & 31.5 \\
\hline Fenerbahçe & 3 & 17 & 24 & 44 & 222 & 102 & 30 & 442 \\
(n, \%) & 0.7 & 3.8 & 5.4 & 10 & 50.2 & 23.1 & 6.8 & 35.7 \\
\hline Kayserispor & 17 & 52 & 117 & 66 & 71 & 68 & 14 & 405 \\
(n, \%) & 4.2 & 12.8 & 28.9 & 16.3 & 17.5 & 16.8 & 3.5 & 32.7 \\
\hline Total & 26 & 93 & 199 & 158 & 452 & 250 & 59 & 1237 \\
(n, \%) & 2.1 & 7.5 & 16.1 & 12.8 & 36.5 & 20.2 & 4.8 & 100 \\
\hline
\end{tabular}

Table 4. Distribution according to occupational status of participants

\begin{tabular}{|l|c|c|c|c|c|c|c|c|}
\hline \multicolumn{1}{|c|}{ Club } & $\begin{array}{c}\text { Full time } \\
\text { Job }\end{array}$ & $\begin{array}{c}\text { Part time } \\
\text { Job }\end{array}$ & $\begin{array}{c}\text { House } \\
\text { wife }\end{array}$ & Student & Retired & Unemployed & Self-Employment & Total \\
\hline Galatasaray & 142 & 21 & 1 & 196 & 30 & 8 & 19 & 390 \\
(n, \%) & 36.4 & 5.4 & 0.3 & 50.3 & 0.8 & 2.1 & 4.9 & 31.5 \\
\hline Fenerbahçe & 172 & 23 & 1 & 211 & 4 & 7 & 24 & 442 \\
(n, \%) & 38.9 & 5.2 & 0.2 & 47.7 & 0.9 & 1.6 & 5.4 & 35.7 \\
\hline Kayserispor & 144 & 25 & 4 & 183 & 7 & 12 & 30 & 405 \\
(n, \%) & 35.6 & 6.2 & 1 & 45.2 & 1.7 & 3 & 7.4 & 32.7 \\
\hline Total & 458 & 69 & 6 & 590 & 14 & 27 & 73 & 1237 \\
(n, \%) & 37 & 5.6 & 0.6 & 47.7 & 1.1 & 2.2 & 5.9 & 100 \\
\hline
\end{tabular}

Stadium Attendance and Non-Attendance Reason Scale (SANARS). Factor analysis results. Exploratory factor analysis gave a basic structure of the data in the identification matrix and this structure (Hair, Anderson, Tahtam, \& Black 1998). Load factors were calculated in all scales and in the exploratory factor analysis, principal component analysis and varimax rotation techniques were applied. Eigenvalues for factors greater than 1 were calculated. The scale used for exploratory factor analysis in research is shown in Tables 5 and 6.

A test showing that from the outset the validity of a factor analysis KMO (Kaiser-Meyer-Olkin) test serves to measure the sample size. Over $60 \%$ of the $\mathrm{KMO}$ values allowed to continue the analysis of the sample size (Nakip, 2003). Also high values of $\chi^{2}$ and $p$ are $5 \%$ of the levels and are necessary to be significant.

As seen in Table 5, the three different Super League supporters applied to scale attendance in the stadium exploratory factor analysis is greater than $60 \%$ of KMO value. As a result, $(0.86)$, a high value of $\chi^{2}$ was found at $p=.000$. All of these results and our data indicate that the sample size is adequate for factor analysis. When the total explained variance was examined, it was found that $55.10 \%$ of the announced models contained measurements of the dimensions that make up the scale of attendance in the stadium.

As seen in Table 6, the three Different Super League supporters pertaining to stadium attendance resulted in an exploratory factor analysis greater than $60 \%$ of KMO (0.92), a high value of $\chi^{2}$ and was found to be $p=.000$. All of these results and our data indicate that the sample size is adequate for factor analysis. When the total explained variance was examined it was found that $58.15 \%$ of the announced models contained measurements of the dimensions that made up the scale to attendance in the stadium. 
Table 5. Reasons of Super League Football Team Fans Attendance in the Stadium Scale factor analysis and load values

\begin{tabular}{|c|c|c|c|}
\hline $\begin{array}{ll}\text { Factor Load Values } \\
\text { Materials }\end{array}$ & Factor 1 & Factor 2 & Factor 3 \\
\hline \multicolumn{4}{|c|}{$\begin{array}{l}\text { Opportunity for Recreational Activities } \\
\qquad(\alpha=.85, V E=33.52 \%)\end{array}$} \\
\hline Enjoyment of Sports Competitions & 0.83 & & \\
\hline Having a Good Time & 0.80 & & \\
\hline Relaxation & 0.73 & & \\
\hline Game's Excitement & 0.72 & & \\
\hline \multicolumn{4}{|c|}{$\begin{array}{l}\text { Stadium Atmosphere } \\
(\alpha=.71, V E=11.42 \%)\end{array}$} \\
\hline Stadium Entertainment & & 0.78 & \\
\hline Social Interaction & & 0.74 & \\
\hline Competitive Atmosphere & & 0.59 & \\
\hline Star Player & & 0.53 & \\
\hline \multicolumn{4}{|c|}{$\begin{array}{l}\text { Opportunities for Personal Relaxation } \\
\qquad(\alpha=.77, V E=10.15 \%)\end{array}$} \\
\hline Forget About My Problems & & & 0.82 \\
\hline Get Away from Everyday Routine & & & 0.77 \\
\hline Throw Stress Out & & & 0.62 \\
\hline \multicolumn{4}{|c|}{$\begin{array}{c}\quad N=1237 ; \mathrm{KMO}=0.86 \\
\text { Bartlett's Sph. } \chi^{2}=6.51 \mathrm{E3} ; p=.000 \\
\text { Total Announced Variance }=55.10 \%\end{array}$} \\
\hline
\end{tabular}

Table 6. Reasons of Super League Football Team Fan Non-Attendance in the Stadium Scale factor analysis load values

\begin{tabular}{|c|c|c|c|}
\hline \multicolumn{2}{|r|}{ Factor Load Values } & Factor 1 & Factor 2 \\
\hline \multicolumn{4}{|c|}{$\begin{array}{l}\text { Negative Ergonomic Environment } \\
\qquad(\alpha=.90, V E=47.94 \%)\end{array}$} \\
\hline Traffic Problems & & 0.81 & \\
\hline Parking Difficulty & & 0.78 & \\
\hline Problem of Stadium E & d Exit & 0.76 & \\
\hline Uncomfortable Seat & & 0.75 & \\
\hline Bad Weather & & 0.73 & \\
\hline Time Conflicts & & 0.72 & \\
\hline Bad Sightlines & & 0.65 & \\
\hline Dirty Conditions & & 0.62 & \\
\hline \multicolumn{4}{|c|}{$\begin{array}{c}\text { Non Ethical Issues } \\
(\alpha=.78, V E=10.21 \%)\end{array}$} \\
\hline Violence & & & 0.85 \\
\hline Profanity & & & 0.79 \\
\hline Too much drinking & & & 0.63 \\
\hline \multicolumn{4}{|c|}{$\begin{array}{l}\qquad N=1237 ; \mathrm{KMO}=0.92 \\
\text { Bartlett's Sph. } \chi^{2}=1.004 \mathrm{E} 4 ; p \\
\text { Total Announced Variance }=5\end{array}$} \\
\hline
\end{tabular}




\section{DISCUSSION}

In this study, 1137 male supporters (91.9\%), 100 female supporters participated (8.1\%) and comprised a total of 1237 subjects. The results of this study showed similarities to Inan's (2007) study. Inan (2007) investigated 3790 professional football fans including male supporters $(87.6 \%)$ and female supporters (12.4\%). Gencer and Aycan (2008) studied 267 spectators that were professional football team fans, 94\% males and 6\% females. Sportfive (2002) concluded that football fans in Germany were predominated by males. Estimates on the results of the studies carried out indicate that of all stadium visitors, $27.2 \%$ were women. Results from 2007 to 2014 showed that there was no percentage change in the number of women in the audience.

Supporters (79.4\%) who participated in the study were under the age of 30 (Tablel). In his study of the Super League teams of 3790, Inan (2007) found that $54.5 \%$ of the fans determined were in the15-24 age range. Ozmaden (2005) established that in the 2001-2002 season professional super league audience, there were 2380 fans, and $56.3 \%$ of the audience were in the 19-28 age range. Gencer and Aycan (2008) found that $66.7 \%$ professional football audience was 27 years old and under. According to Sportfive (2002), the participants in the football match in Germany the averagely aged 26.6 years and the rate was not representative of the whole crowd. In this survey, $15.7 \%$ of the football fans in Germany were over 50 years of age. These results show that more than $50 \%$ of football fans are under the age of 30 years.

In our study $36.5 \%$ of the respondents were university students and $20.2 \%$ were university graduates (Table 3). In addition, among the fans who participated in the study, $61.5 \%$ were found to be affiliated with the university and higher education. Galatasaray supporters were comprised university students at a rate of $40.8 \%$, Fenerbahce supporters were university students at a rate of $50.2 \%$. and $28.9 \%$ of Kayserispor fans were high school students. When studying Fenerbahce soccer fans, it was observed that the levels of education of $52.2 \%$ of fans were high school graduates (Salman \& Giray, 2010).

As a result of a factor analysis conducted for the study, the factors most strongly found to account for professional football fan stadium attendance were the respective areas of: Recreation Activities
Opportunities (4 items), Stadium Atmosphere (4 items) and Personal Relaxation Opportunity (3 items). The professional football team supporters load value of the components that effect stadium nonattendance are: Negative Ergonomic Environment (Article 8) and Non-Ethical Situations (3 items). Gencer and Aycan (2008) found load components which most effected fan's decisions to attend were professional football competitions were as follows: Supported Teams, Socialization Opportunities, Physical Environment, Charm of Competition, Compliance of the Program and Competitors Team.

Of all the factors affecting professional football fan stadium attendance, the "Recreation Activities Opportunities" component was found to be the most influential factor. This information reveals that fans spend more recreational time for reasons arising from their own needs. According to a study by Salman and Giray (2010), football fans attended games as part of social group relations. If one compares the effect of factors motivating the attending of spectator sports competitions, athletes and the fans clearly stated different needs (Green, 2003). In research by Funk and James (2001) sports fans cited as social interaction as motivation for their attendance. Research by Gladden and Funk (2002) pointed out that being included in the peer group is the driving force in attending German football contests.

In this research, the "stadium atmosphere" component was found to be the second most important factor affecting the professional football fans attendance to the stadium. Morrow (2003) reported that FC Copenhagen (Denmark) football fans attended to experience being on television images that portray a fun stadium atmosphere, which can draw many more spectators to come to the stadium. Guschwan (2007) reported that Italian spectators were not only watching the match at the same time but also singing during the carnival atmosphere, which takes place throughout the game in addition to various political and cultural protests that are taking pace by fans of both teams regarding many issues. According to Morrow (1999), customers are not only the audience in the stadium; they represent an actual part of the game. The audience creates excitement in the stadium, which changes the stadium atmosphere during the match. The stadium atmosphere can affect ticket sales, and is an important factor affecting the television broadcast. 
With professional football fans, a third major factor affecting the participation of the stadium is "Opportunity of personal relaxation". Wann (1997) put forth that the most common motives of fan attendance are: pleasant tension, self-esteem, escape, entertainment, economic, aesthetic, connection to the group status and the family needs. Guschwan (2007) pointed out that Italian fans are not only watching the game, but also enjoying the stadium atmosphere. This kind of social interaction allows the fan to live in an inner world forgetting their problems, and providing them happiness.

In our research the most important factor affecting non-attendance to the stadium was "Negative ergonomic environment" component. The most influential factors related to negative ergonomic environment were the weakness of the quality of services performed in the stadium. The research Also found that the physical and social environment of live sporting events have been widely accepted (Tombs \& McColl-Kennedy, 2003; Wakefield \& Blodgett, 1999; Westerbeek \& Shilbury, 1999; Wakefield \& Sloan, 1995).

The second most influential factor affecting professional football fans non-attendance to the stadium was found to be "Non-Ethical Situations" such as negative attitudes and carrying out poor behavior in stadiums. Such situations can affect result in fans choosing not to attend further contests at the stadium. More specifically, violence, profanity, and too much alcohol consumption make fans not attend sporting events taking place at the stadium. Alcohol consumption starts several hours before the fans are come to the area around the stadium and continues during the game while in the stadium.

\section{CONCLUSION}

In our research the determined most influential factors affecting professional football team stadium attendance are: opportunities of recreational activities, stadium atmosphere, and opportunity of personal relaxation. In this case it was found that professional football fans were coming to the stadium to have a good time. Football fans were found to be affected by the atmosphere of the stadium. Attendees used the stadium as a personal relaxation tool. The main purpose of going to the stadium of football fans was not to be a loyal supporter but to have a good time. As the organization of recreation and quality time increases so should the fan attendance.
Factors affecting the reasons for non-attendance in the stadium by professional football fans were found to be: negative ergonomic environment and non-ethical issues. Based on these results of our stadium research negative ergonomic environment was found to be weak.

One of the most important revenue streams of professional football clubs is income generated by fan attendance of the stadium. In this regard, it is important that stadium attendance for the football clubs remains strong. Sports fans and audiences are important parts of the sports consumer. Sports teams and clubs, in an effort to reach more consumers are spending great amount of effort to increase the sale of tickets and team products.

If we consider stadiums as a market, sport spectator as sport consumers need to be brought together to merge the two concepts. The sports consumer satisfaction is of great importance. The attendance of a greater number of spectators to the stadium as the football team improves its success will provide very substantial financial gains to the football club. In turn, as financial gains increase, more quality players and technical staff will be obtainable, making it possible to participate at a higher level of competition.

Stadiums are not reserved only for athletic competitions. Thousands of sports spectators also attend stadiums for recreational activity. The spectators spend a good time with family and friends; meet with supporters of the team fans, which enters into an enjoyable social interaction at the sport venue. For the aforementioned reasons, architects involved in the process of stadium construction will make stadiums more convenient for audiences, including detailed designs to ensure optimal comfort for the fans.

\section{RECOMMENDATIONS}

- It is recommended that increases in the stadium should take place in the areas of recreation and the quality of service.

- In order to provide the best atmosphere of the stadium, it is especially recommended that a good acoustics design is included in the stadium.

- Ergonomically the stadium and the surrounding environment should be prepared for ease of use by people.

- The following necessary points of businesses are recommended to be provided in the stadium, for optimal service. 
- Toilet must conform to the standards of hygiene.

- Extremely good team performance is required.

- Fans must be informed about their ethical rules through posters and announcements.

- Necessary punitive measures should be enforced when fans display negative behavior.

- Highly intoxicated fans should be prevented from entering the stadium.

- The location of the stadium must be determined to be safe.
- If the stadium facilities are far from the city center, convenient transportation must be provided.

- People who manage the football clubs must be ethical, stable and respected by the community.

- Ample parking spaces need to be available at stadiums.

- Necessary security measures to ensure the safety of fans' family and friends should be provided.

\section{REFERENCES}

Argeris, S., \& Nagel, M. S. (2013). An investigation of Major League Soccer attendance. Journal of Venue and Event Management, 4(2), 64-75.

Bauer, H. H., Sauer, N. E., \& Exler, S. (2005). The loyalty of German soccer fans: Does a team's brand image matter? International Journal of Sports Marketing and Sponsorship, 7(1), 8-16. https://doi.org/10.1108/ IJSMS-07-01-2005-B004

Borland, J., \& MacDonald, R. (2003). Demand for sport. Oxford Review of Economic Policy, 19(4), 478-502. https://doi.org/10.1093/oxrep/19.4.478

Clapp, C. M., \& Hakes, J. K. (2005). How long a honeymoon? The effect of new stadiums on attendance in Major League Baseball. Journal of Sports Economics, 6(3), 237-263. https://doi. org/ $10.1177 \% 2$ F 1527002504265957

DeSchriver, T. D., Rascher, D. A., \& Shapiro, S. L. (2016). If we build it, will they come? Examining the effect of expansion teams and soccer-specific stadiums on Major League Soccer attendance. Sport, Business and Management: An International Journal, 6(2), 205-227.

Ekmekci, R., \& Ekmekçi, A. (2010). Sport marketing. Pamukkale Spor Bilimleri Dergisi, 1(1), 23-30.

Funk, D. C., \& James, J. (2001). The psychological continuum model: A conceptual framework for understanding an individual's psychological connection to sport. Sport Management Review, 4(2), 119-150. https://doi.org/10.1016/S1441-3523(01)70072-1

Futbol, A. T. E. (2005). Literatur Yayınları, 1. Baskl, Istanbul, 3(9), 299.

Gençer, R.T., \& Aycan, A. (2008). Variables analysis of decision of affecting the audience participation in professional football competition. Ege Academic, 8(2), 771-783.

Gladden, J. M., \& Funk, D. C. (2002). Developing an understanding of brand associations in team sport: Empirical evidence from consumers of professional sport. Journal of Sport Management, 16(1), 54-81. https://doi.org/10.1123/jsm.16.1.54
Green, B. C., Parks, J. B., \& Quarterman, J. (2003). Psychology of sport consumer behavior. Contemporary Sport Management, 2, 127-146.

Guschwan, M. (2007). Riot in the curve: Soccer fans in twenty-first century Italy. Soccer \& Society, 8(2-3), 250-266. https://doi.org/10.1080/14660970701224467

Hair, J. F., Black, W. C., Babin, B. J., Anderson, R. E., \& Tatham, R. L. (2006). Multivariate data analysis 6th Edition. Pearson Prentice Hall. New Jersey. Humans: Critique and reformulation. Journal of Abnormal Psychology, 87, 49-74.

Holt, D. B. (1995). How consumers consume: A typology of consumption practices. Journal of Consumer Research, 22(1), 1-16. https://doi.org/10.1086/209431

İnan, T. (2007). Examination of applications in order to increase the ticket sales of football clubs in Turkey (Doctoral dissertation). Adana: Cukurova University, Institute of Health Sciences.

Kelley, S. W., \& Turley, L. W. (2001). Consumer perceptions of service quality attributes at sporting events. Journal of Business Research, 54(2), 161-166. https://doi.org/10.1016/S0148-2963(99)00084-3

Kotab, J., \& Scholleva, H. (2011). Evaluations in football player's contracts. XIII IASE and III ESEA Conferences on Sports Economics. Prague.

Madrigal, R. (1995). Cognitive and affective determinants of fan satisfaction with sporting event attendance. Journal of Leisure Research, 27(3), 205-227. https://doi. org/10.1080/00222216.1995.11949745

McEvoy, C. D., Nagel, M. S., DeSchriver, T. D., \& Brown, M. T. (2005). Facility age and attendance in Major League Baseball. Sport Management Review, 8(1), 19-41. https://doi.org/10.1016/S1441-3523(05)70031-0 Morrow, S. (2003). The people's game. Football, finance and society. New York: Palgrave Macmillan.

Nakip, M. (2003). Marketing research (techniques and spss aided applications). Ankara: Seckin Publishing House. 
Noll, R. G. (1997). Sports, jobs \& taxes. The economic impact of sports teams and stadiums (pp. 55-91). RG Noll \& A. Zimbalist.

Özmaden, M. (2005). According to the football spectators: Audience behavior aggression effects of competitor's audience. Kastamonu Education Journal, 13(2), 663-674.

Pfaff, S. (2002). Experiential Marketing for the visitors of sports events - Experience strategies and - instruments for the German Bundesliga (Unpublished doctoral dissertation). Germany: University of Göttingen,

Salman, G. G, \& Giray, C. Ö. (2010). The relationship between incentives and loyalty that affects individuals of football fans: an application on Fenerbahce fans. Marmara University Institute of Social Sciences Journal, 9(33), 89-97.

Solberg, H. A., \& Gratton, C. (2004). Would European soccer clubs benefit from playing in a Super League? Soccer \& Society, 5(1), 61-81. https://doi.org/10.1080/ 14660970512331391004

Sportfive (2002). European football: Markets, events, clubs, media, brands. Hamburg, Germany: Sportfive.

Szymanski, S. (2003). The economic design of sporting contests. Journal of Economic Literature, 41(4), 11371187. doi: 10.1257/002205103771800004

Tombs, A., \& McColl-Kennedy, J. R. (2003). Social-servicescape conceptual model. Marketing theory, 3(4), 447475. https://doi.org/10.1177\%2F1470593103040785
Uhrich, S., \& Benkenstein, M. (2010). Sport stadium atmosphere: formative and reflective indicators for operationalizing the construct. Journal of Sport Management, 24(2), 211-237. https://doi.org/10.1123/jsm.24.2.211

Wakefield, K. L., \& Blodgett, J. G. (1994). The importance of servicescapes in leisure service settings. Journal of Services Marketing, 8(3), 66-76. https://doi. org/10.1108/08876049410065624

Wakefield, K. L., \& Blodgett, J. G. (1999). Customer response to intangible and tangible service factors. Psychology \& Marketing, 16(1), 51-68. https://doi. org/10.1002/(SICI)1520-6793(199901)16

Wakefield, K. L., \& Sloan, H. J. (1995). The effects of team loyalty and selected stadium factors on spectator attendance. Journal of Sport Management, 9(2), 153172. https://doi.org/10.1123/jsm.9.2.153

Wann, D. L., Royalty, J. L., \& Rochelle, A. R. (2002). Using motivation and team identification to predict sport fans' emotional responses to team performance. Journal of Sport Behavior, 25(2), 207-217.

Westerbeek, H. M., \& Shilbury, D. (1999). Increasing the focus on "place" in the marketing mix for facility dependent sport services. Sport Management Review, 2(1), 1-23. https://doi.org/10.1016/S14413523(99)70087-2

Yoshida, M., \& James, J. D. (2010). Customer satisfaction with game and service experiences: Antecedents and consequences. Journal of Sport Management, 24(3), 338-361. https://doi.org/10.1123/jsm.24.3.338 